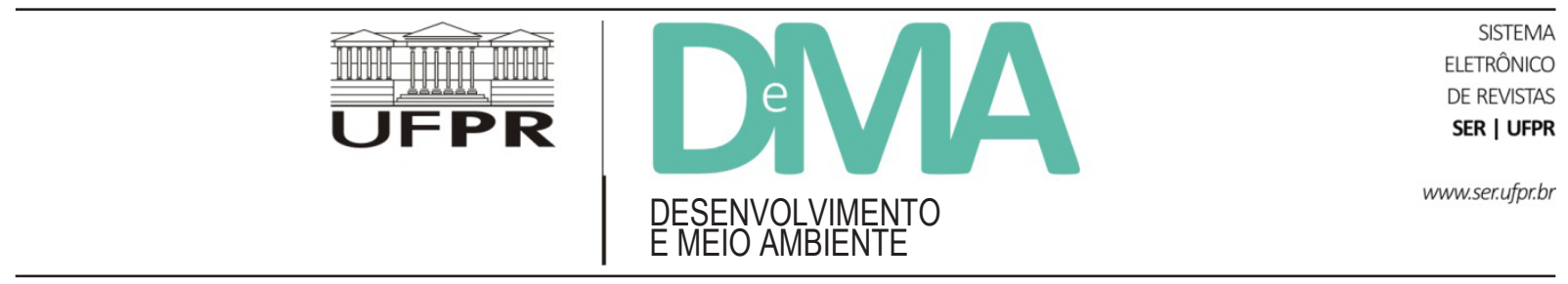

\title{
Homenagem da revista Inf'OGM, Veille citoyenne sur les OGM et les semences ${ }^{1}$
}

Magda Zanoni nous a quittés le 10 mars 2015.

Nous, salarié-e-s et administrateur-rice-s d'Inf'OGM, sommes encore sous le coup.

Chercheuse généreuse, militante, citoyenne, elle a vécu guidée par un rêve : un monde plus juste, plus respectueux de la vie, plus joyeux.

Mais elle n'a pas que rêvé : elle s'est battue, elle s'est mobilisée au Brésil et en Europe.

Pour défendre les réformes agraires dans un grand pays où les latifundia côtoient des paysans sans terre... Pour faire reconnaître une agriculture familiale et paysanne que Magda voyait comme permettant de nourrir les hommes, protéger le climat, préserver la biodiversité et renforcer l'autonomie des paysans. Cette agriculture, à l'opposé des OGM qu'elle a combattus sans relâche, est la seule, sou- tenait-elle, à garantir la sécurité et la souveraineté alimentaires.

Nous nous souvenons de ses interventions à la CTNBio, la Commission technique nationale de biosécurité, qui au Brésil, gère les autorisations des plantes génétiquement modifiées. Elle n'a pas compté ses heures, sa sueur, pour s'opposer aux promoteurs des OGM, à leur soutien politique et leurs pratiques peu scrupuleuses de lobby.

Magda était pour nous non seulement une collègue, une chercheuse qui nous aidait à comprendre les enjeux politiques de son pays, qui répondait toujours avec précision à nos questions, mais aussi une amie. Une amie qui avait caché sa maladie pour ne pas se faire plaindre. Elle se battait contre sa maladie comme elle s'est battue dans sa vie militante. Merci, Magda, Merci. 